\title{
Clinical Reasoning and Critical Thinking
}

\author{
Josinete Aparecida da Silva Bastos Cerullo ${ }^{1}$ \\ Diná de Almeida Lopes Monteiro da Cruz $^{2}$
}

\begin{abstract}
This study identifies and analyzes nursing literature on clinical reasoning and critical thinking. A bibliographical search was performed in LILACS, SCIELO, PUBMED and CINAHL databases, followed by selection of abstracts and the reading of full texts. Through the review we verified that clinical reasoning develops from scientific and professional knowledge, is permeated by ethical decisions and nurses' values and also that there are different personal and institutional strategies that might improve the critical thinking and clinical reasoning of nurses. Further research and evaluation of educational programs on clinical reasoning that integrate psychosocial responses to physiological responses of people cared by nurses is needed.
\end{abstract}

Descriptors: Diagnosis, Clinical; Nursing Diagnosis; Nursing Process. 


\title{
Raciocínio clínico e pensamento crítico
}

O objetivo deste trabalho foi identificar e analisar estudos da literatura de enfermagem sobre raciocínio clínico e pensamento crítico. Realizou-se busca bibliográfica nas bases de dados LILACS, SciELO, PubMed e CINAHL, escolha de resumos, com posterior leitura dos textos na íntegra. Essa revisão permitiu verificar que o raciocínio clínico se desenvolve a partir dos conhecimentos científicos e profissionais, permeado por decisões éticas e valores dos enfermeiros e, ainda, que existem diversas estratégias pessoais e institucionais que podem aprimorar o pensamento crítico e raciocínio clínico dos enfermeiros e que há necessidade de realizar pesquisas e avaliação de programas de formação sobre raciocínio clínico que integrem as respostas psicossociais às fisiológicas das pessoas cuidadas pela enfermagem.

Descritores: Diagnóstico Clínico; Diagnóstico de Enfermagem; Processos de Enfermagem.

\section{Raciocinio clínico y pensamiento crítico}

\begin{abstract}
El objetivo de este trabajo fue identificar y analizar estudios de la literatura de enfermería sobre raciocinio clínico y pensamiento crítico. Se realizó una búsqueda bibliográfica en las bases de datos LILACS, SciELO, PubMed y CINAHL, selección de resúmenes, con posterior lectura completa de los textos. Esa revisión permitió verificar que el raciocinio clínico se desarrolla a partir de los conocimientos científicos y profesionales, impregnado por decisiones éticas y valores de los enfermeros $y$, también, que existen diversas estrategias personales e institucionales que pueden perfeccionar el pensamiento crítico y raciocinio clínico de los enfermeros y que existe necesidad de realizar investigaciones y evaluación de programas de formación sobre raciocinio clínico que integren las respuestas psicosociales a las fisiológicas de las personas cuidadas por la enfermería.
\end{abstract}

Descriptores: Diagnóstico Clínico; Diagnóstico de Enfermería; Procesos de Enfermería.

\section{Introduction}

The term clinical reasoning is used in scientific literature to describe the mental processes involved in the care delivered to users of healthcare systems. The word reasoning comes from the Latin word raciocinium - calculation, evaluation, use of reason, whereas clinical derives from the Greek word klinikos - bed, clinic, place where preventive, curative and palliative procedures are carried out or analysis of the signs and symptoms manifested by patients ${ }^{(1)}$.

Clinical reasoning is a central theme for nursing professionals' practice and teaching. This article presents an overview of strategies to improve clinical reasoning, based on the scientific nursing literature on this topic.

Aiming to outline scientific production in the field, a bibliographic search was performed in January 2008 in LILACS, SciELO, PubMed and CINAHL databases without limitation of date of publication, observing the available abstracts.
The terms raciocínio clínico and 'clinical reasoning' were not found either in MeSH (PubMed) or DeCS (BIREME), so the search focused on the use of these words in titles and abstracts. After the initial search, we found that many articles addressed the issue pensamento crítico and 'critical thinking', so new searches were conducted using these terms, since these were not indexers either.

There was a superposition of many references, and after careful reading and analysis of the abstracts in Portuguese, Spanish and English, the 25 selected publications were fully read to compose this article.

\section{Specific Reasoning in Clinical Nursing}

Clinical reasoning is present in all nurses' care actions and decisions: in diagnosing phenomena, in choosing appropriate interventions and evaluating results. The 
formulation of the diagnosis includes expectations of interventions and potential outcomes in a given context and depends on the people involved (nurse, patient, family, community) and the relationships established between them ${ }^{(2)}$.

The studies on clinical reasoning in nursing can be divided according to date of publication and thematic influence: the 1970s - based on statistical theory, the 1980s - theory of information processing, 1990 intuitive reasoning. Today, there is a variety of studies in these three fields ${ }^{(3)}$.

Decisions based on inductive, deductive and intuitive analyses are also permeated by ethical thinking, so that clinical reasoning is fundamentally an interactive process, contextualized in care practice. Thus, several authors have proposed the integration of these logics existent in the concept of clinical reasoning.

One proposal of a theoretical model of clinical reasoning integrates three dimensions in clinical judgments: the diagnostic dimension, the therapeutic dimension and the ethical dimension ${ }^{(4)}$. According to this model, the collection and processing of information is strongly influenced by ethno-cultural and motivational aspects of subjects, by the nurses' interests and philosophical foundations, their beliefs about nursing's conceptual focus and its social function, and their implicit and explicit values, especially when there is little time for decision-making. Thus, encouraging sensitivity to relevant ethical cues on admission and in daily assessments of patients is very important within an integrated approach.

We suggest that admission assessment is guided by Functional Health Patterns* and techniques of analysis of narrative that can reveal interesting information about the integration of diagnostic, therapeutic and ethical content.

A study in the health milieu(5) ratifies the view that the clinical reasoning of specialist nurses occurs in their experience in delivering care and in attributing values for such care. After analyzing interviews carried out with 11 nurses through Grounded Theory, the author developed a theoretical model of clinical reasoning, which has three main elements: "finding oneself in the challenge of caring," "caring" and "assigning value to care". This model shows that nurses seek relevant information about the person requiring care, as attention is drawn to certain issues and that this is an ongoing process during admission, the implementation of interventions and evaluation of results, permeated by the experience of the values attributed to care (i.e. to like providing care or not, value or devalue nursing, be aware of ethicalmoral dilemmas or not, to know the patient or not, to trust in one's own intellectual abilities or not).

The author stresses that such features summarize how clinical reasoning is developed based on professional knowledge and attention to nurses' internal and external environments, which might generate involvement (or not) and nurse's decision-making about the person to be cared for.

\section{Use of Critical Thinking and Improvement of Clinical Reasoning}

Clinical reasoning and critical thinking are frequently used in nursing literature as synonyms to describe processes associated with the work of nurses with patients. Other terms are used-analytical thinking, clinical judgment, critical judgment, clinical decisionmaking, creative thinking, problem solving, reflective thinking, diagnostic reasoning-however, the way authors explain concepts related to these terms differ considerably.

It does not seem appropriate to consider clinical reasoning and critical thinking as synonymous: critical thinking involves some skills and attitudes necessary for the development of clinical reasoning, which is based on existing knowledge and context (possible goals, needs of patients, available resources).

In an analysis of the literature from 1981-2002, 198 attributes for the term critical thinking were found(6). In this and other studies, the authors mentioned that critical thinking is still an evolving concept in nursing, that there is not a sufficiently clear model of critical thinking and recommend further research on the subject (quantitative or qualitative). Critical thinking would not be a method to be learned, but a process, an orientation of the mind, incorporating the cognitive and affective domains $^{(7)}$.

Two studies, however, are cited as helpful in understanding critical thinking in nursing: one ${ }^{(8)}$ addresses the characterization of critical thinking of nurses through habits of the mind and cognitive skills, and the second ${ }^{(9)}$, presents a theoretical framework that characterizes the clinical experience as the main ally in improving critical thinking.

*The 11 Functional Health Patterns are areas that allow understanding of the health-disease processes: perception and management of health, nutrition, elimination, activity and exercise, rest and sleep, sensory perception, self-perceptions and self-concept, relationships, sexuality and reproduction, adaptation and stress tolerance, beliefs and values. It is a structured and holistic approach to the assessment of the admission of people, their development and quality of life. 
The enhancement of critical thinking is key to achieving high standards of diagnostic accuracy, since the proposition of diagnoses and interventions is a complex task(10).

The strategies that can be employed to improve critical thinking are(11-14):

- to reflect on one's own life and personal values and the development of relationships with patients and one's profession;

- to recognize and promote a work environment that values nurses as knowledgeable workers and invites them to debate and question;

- to think about one's own thinking (for example, following the proposal of the 7 cognitive skills and 10 habits of mind);

- to connect with the thinking of others;

- to identify and challenge assumptions, inferences and other interpretations;

- to consider alternative possibilities and make use of reflective skepticism;

- to balance reflective skepticism - one's own truth and those of others;

- to develop sensitivity to contextual factors;

- to assess the credibility of evidence;

- to recognize and accept intuitive knowledge;

- to tolerate the ambiguity of clinical judgments;

- to control anxiety about the possibility of being

"wrong".

Institutions can also promote the improvement of critical thinking $(7,12-13,15)$ through:

- the offering of educational opportunities appropriate to different learning styles;

- teaching approaches that encourage creativity, testing, discovery and questions (e-mails, texts, poetry, debate);

- carrying out activities in small groups;

- the use of role development techniques;

- reading articles and writing critical essays;

- simulations, puzzles and analysis of representations in the media (newspapers, magazines);

- analysis of case studies and clinical scenarios;

- development of projects proposing changes;

- adopting the strategy of PBL (Problem Based Learning);

- encouraging the participation of nurses in the decisionmaking process in clinical units;

- encouraging dialogue among peers, which favors proactive processes;

- supporting a formal and informal organizational culture for nursing professional development.
Potential barriers to improved critical thinking are: conflicts at the work place (repetitive solutions, impaired ability to listen, troubled relationships among nurses or nurses and physicians), the stereotyped use of diagnostic categories, specialization and excessive demands on nurses' time ${ }^{(13)}$.

\section{Methods to Evaluate Critical Thinking}

The evaluation of critical thinking can be accomplished through several strategies: through instruments, observation of performance in a practical environment, use of questions for clarification, discussions about patient care, problem-solving strategies using case scenarios and the indication of interventions, analysis of written portfolios, documentation of situational analysis and conceptual maps. Evaluating only one strategy or only once is not recommended $(7,13)$.

The found instruments that measure critical thinking were:

- Watson-Glaser Critical Thinking Appraisal(16);

- California Critical Thinking Skills Test ${ }^{(17)}$;

- Ennis Weir Critical Thinking Essay Test ${ }^{(18)}$;

- Cornell Critical Thinking Test(19);

- California Critical Thinking Disposition Inventory(20).

The main limitations for the use of these instruments in nursing are that they do not capture the specific nature of nursing, do not incorporate nurses practical reality, are usually applied to populations of students, are not randomized and do not have wellestablished psychometric properties. A review of the concept of critical thinking, as well as the evaluation of critical thinking in the clinical context with multiple measurements, is recommended(21-23).

There is also specific criticism about existent research - that the use of critical thinking (focused on analytical and individual thinking) would not ensure the development of the nursing profession because it would decrease creativity, the dialogical interaction with people and communities and would not structure practice in nursing theories ${ }^{(21,24)}$. This view seems to be very extreme because, by themselves, skills and attitudes relevant to critical thinking do not limit any human interaction, or the choice of certain theoretical frameworks.

There is no need, however, to transform critical thinking into a unit of course content to be taught in the nursing curriculum, which would indicate an overvalued 
belief in the ability of transformation that this concept would generate. Nonetheless, paradoxically, faculty members and students should be able to observe their own processes of thinking in the cognitive, affective and psychomotor domains, using strategies associated with different contents so that they are able to provide safe and effective care ${ }^{(25)}$.

\section{Conclusions}

Constant improvement of clinical reasoning is a challenge for all professionals in the health field. It requires the use of multiple strategies and ongoing training. There are several studies in the field of hospital nursing that aim to encourage the improvement of clinical reasoning through activities involving information processing, such as discussions of patients' cases.

However there are few studies favoring the improvement of clinical reasoning, including reflexive strategies, which seem more appropriate when one considers clinical reasoning models that also include psychosocial issues and stress the expression of nurses' values and the ethical and moral dilemmas they experience. There is, therefore, a gap of knowledge on the subject and the need to test strategies and carry out further research.
Conducting studies on the improvement of clinical reasoning with the integration of psychosocial responses to the physiological ones is a challenge, since both interfere with the complex health/disease process and demand specific care for individuals and populations.

Considering the need to value the different standards of knowledge and learning styles, the training programs in the field should be planned and implemented based on the practice and experience of the participants, offering opportunities to improve skills, knowledge and attitudes in their own work environment.

Yet, providing educational opportunities does not necessarily imply changes in practice. Professionals are free to modify their work routine or not, based on their own perceptions and contextual influences, which hinders the measurement of the direct impact of these programs on care delivered to the health system's users.

On the other hand, not offering these opportunities is equivalent to assuming that changes will occur through individual and not coordinated initiatives, which might require more time and end in emotional distress for the professionals involved in addition to higher financial costs for professionals and the health system.

Investment in the training of nurses is needed. It is also extremely important to observe its results, especially to evaluate the transformations in cognitive processes and proposed changes in care practices.

\section{References}

1. Houaiss A, Villar MS. Dicionário Houaiss da Língua Portuguesa. Rio de Janeiro (RJ): Objetiva; 2001.

2. Tanner CA. Thinking like a nurse: a research-based model of clinical judgment in nursing. J Nurs Educ 2006; 45(6):204-11.

3. Lee J, Chan ACM, Phillips DR. Diagnostic practise in nursing: a critical review of the literature. Nurs Health Sci 2006; 8:57-65.

4. Gordon M, Murphy CP, Candee D, Hiltunen E. Clinical judgment: an integrated model. Adv Nurs Sci 1994; 16(4):55-70.

5. Correa CG. Raciocínio clínico: o desafio do cuidar. [tese]. São Paulo (SP): Escola de Enfermagem/USP; 2003.

6. Turner $P$. Critical thinking in nursing education and practice as defined in the literature. Nurs Educ Perspect 2005; 26(5):272-7.

7. Simpson E, Courtney M. Critical thinking in nursing education: literature review. Int J Nurs Pract 2002; 8(2):89-98.

8. Scheffer BK, Rubenfeld GM. A consensus statement on critical thinking in nursing. J Nurs Educ 2000; 39(8):352-9.

9. Benner P. From novice to expert: excellence and power in clinical nursing practice. Reading (MA): Addison-Wesley; 1984. 10. Lunney M. Critical thinking and accuracy of nurses diagnoses. Part I: risk of low accuracy diagnoses and nex views of critical thinking. Rev Esc Enferm USP 2003; 37(2):17-24.

11. Lauterbach SS, Becker PH. Caring for self: becoming a self reflective nurse. Holist Nurs Pract 1996; 10(2):57-68.
12. Crowe MT. O'Malley J. Teaching critical reflection skills for advanced mental health nursing practice: a deconstructivereconstructive approach. J Adv Nurs 2006; 56(1):79-87.

13. Hynes P, Bennett J. About critical thinking. Dynamics 2004; 15(3):26-9.

14. Lunney M. Critical thinking and accuracy of nurses diagnoses. Part II: application of cognitive skills and guidelines for selfdevelopment. Rev Esc Enferm USP 2003; 37(3):106-12.

15. Lunney M. Critical thinking and nursing diagnosis: case studies e analyses. Philadelphia: North American Nursing Diagnosis Association; 2001.

16. Watson G, Glaser EM. Watson-Glaser critical thinking appraisal manual. Cleveland: Psychological Corp; 1980.

17. Facione PA. The Califórnia critical thinking skills test manual. Millbrae: California Academic Press; 1992.

18. Ennis RH, Weir E. The Ennis-Weir critical thinking essay test. Pacific Grove: Midwest Publications; 1985.

19. Ennis RH, Millman J, Tomko TN. Cornell critical thinking tests level $X$ and level $Z$ manual. 3rd ed. Pacific Grove: Midwest Publications; 1985.

20. Facione NC, Facione PA. The California critical thinking dispositions inventory test manual. Millbrae: California Academic Press; 1992.

21. Hicks FD. Critical thinking; toward a nursing science 
perspective. Nurs Sci Q 2001; 14(1):14-21.

22. Brunt BA. Models, measurement, and strategies in developing critical thinking skills. J Contin Educ Nurs 2005; 36(6):255-62.

23. Banning $M$. Nursing research: perspectives on critical thinking. Br J Nurs 2006; 15(8):458-61.
24. Cody WK. Critical thinking and nursing science: judgment or vision? Nurs Sci Q 2002; 15(3):184-9.

25. Lima MAC, Cassiani SHB. Pensamento crítico: um enfoque na educação de enfermagem. Rev Latino-am Enfermagem 2000; 8(1):23-30.

Received: Mar. 27th 2009

Accepted: Jul. $28^{\text {th }} 2009$ 